\title{
Assessment of Pension Coverage in the Russian Federation
}

\author{
Sabitova N.M. \\ Jourkina N.S.
}

Kazan Federal University, Institute of Management, Economics and Finance, Kazan, 420008, Russia

\section{Doi:10.5901/mjss.2014.v5n24p200}

\section{Abstract}

This article discusses the evaluation of the pension coverage in the Russian Federation in comparison with other countries. Despite the increase in pension benefits, the pension level does not reach the established targets of the International Labour Organization and other international standards. One of the indicators of the pension coverage in all countries is the replacement rate for lost earnings of the insured person, which shows the ratio of the average pension to the size of the average wage. The article presents a comparative analysis of the method for calculation of this ratio in the Russian Federation and in the European countries; the replacement rate for lost earnings in the Russian Federation is recalculated on the basis of European standards.

Keywords: Pension coverage, pension system, average wage, replacement rate for lost earnings, insurance premiums, cost of living.

\section{Introduction}

The standard of living in different countries is estimated inter alia in terms of pension coverage [1]. Pension system varies from country to country. Russia is significantly inferior to most members of the European Union by the level of pension coverage, with the gaps in the level of old age pensions being more than in incomes per capita. Convention \#102 of the International Labour Organization (ILO) "Minimum Standards of Social Security, states that " with the 30 years of work record the old-age pension should be not less than $40 \%$ of wages in the country, and with a longer work record - not less than $40-55 \%$ [2]. The key parameter, which determines the level of pension schemes in the country, is the replacement rate for lost earnings of the insured person. However, the Convention has not been ratified by the Russian Federation, and the replacement rate, which is calculated in the Russian pension practice, differs from the prescribed norms of the International Labour Organization in a number of parameters. Therefore, a comparison of this indicator for the Russian Federation and other countries needs correction. In most countries, the total amount of insurance old-age pensions for long work record is usually $50-70 \%$ of a salary [3] (Table 1).

Table 1. The replacement rate for lost earnings in some countries in 2013

\begin{tabular}{|c|c|c|}
\hline Countries & Average salary in US dollars. & Replacement rate \% \\
\hline USA & 3504 & 41 \\
\hline Germany & 2865 & 60 \\
\hline France & 2845 & 50 \\
\hline Italy & 2368 & 80 \\
\hline Japan & 2313 & 30 \\
\hline Sweden & 2726 & 60 \\
\hline Russia & 841 & 36 \\
\hline
\end{tabular}

In Russia, the replacement rate with average earnings currently stands at around $36 \%$, but with earnings twice the average the replacement rate is lower than $20 \%$. However, when comparing the solidarity replacement rate in Russian with the international standards, it should be born in mind that it takes into account the pension of persons who have not reached the end of 30 years insurance, which in Russia is $23 \%$ of the number of recipients of old-age pension [4]. But the most important thing is the level of population wages in other countries which many times exceed the wages of the Russian population. That is why the size of the replacement rate in Russia is $40 \%$ that corresponds to the level of poverty, i.e. 2.5-3 of the subsistence minimum. The state guarantee of the material security for the Russian pensioners 
does not even reach the level of poverty in most countries of the world [5]. Each sixth subject of the Russian Federation has the ratio of workers to retirees of not more than 1 to 1 This is primarily due to the demographic aging of the population, leading to an increase in the number of pensioners and reduction of employment in the economy [6]. To keep the pensions at the rate of $40 \%$ of the current average nominal accrued wage in the forecast period with such ratio of workers to pensioners the premiums should be $33.6 \%$ of the salary (without size limit for the base calculation of insurance premiums, the overall rate of insurance contributions into the state non-budgetary funds in this case is $42 \%$ ).

In addition, not all employees in the Russian economy pay the premiums to the Pension Fund of the Russian Federation, and individual entrepreneurs, whose number is constantly growing, form their own pension rights on preferential basis - on the basis of the minimum wage. As a result, the value of contributions of this group of citizens is more than 3 times lower than average employee contributions. Thus, the main burden of financial support of statutory pension insurance system is on the employed citizens.

\section{Result}

In recent years, Russia has experienced a downward trend in the replacement rate (see Fig. 1). In late 2009, the value of solidarity in the replacement rate for a medium-sized old-age pension in the Russian Federation was 35.3\%, while in 20 subjects of the Russian Federation, this value was between $30 \%$ and $40 \%$ of average earnings in the region, and in 55 subjects it exceeded $40 \%$ [7].

The growth rate in 2010 was due to the fact that the size of pensions increased significantly in relation to the revaluation of pension rights (valorization of pensions), the beginning of surcharges payment to reach the social subsistence level established in the subject of the Russian Federation, and the establishment of new rules for pension indexation. As a result, the replacement rate has increased to $39 \%$, but then its decline has resumed, despite the ongoing annual indexation of pensions and increasing the level of the average wage.

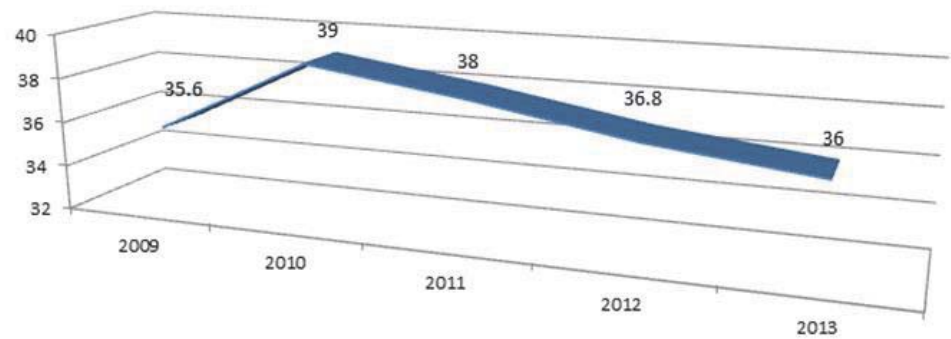

Fig.1. Replacement rate for lost earnings of the insured person in the Russian Federation in 2009-2013, \%

One of the reasons for the decline is that from 2010 to 2013, the growth rate of the average wage (1.42) lagged behind the growth rate of the average labor pension (1.31), as shown by the data in Figure 2.

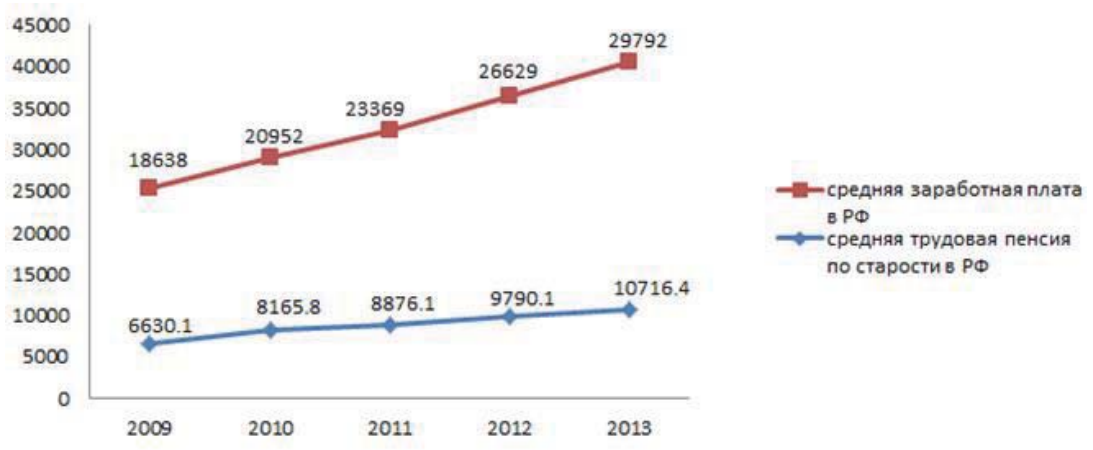

Fig.2. The average salary and the average size of old-age pension in the Russian Federation in 2009 - 2013, in rubles

The reasons for the influence of this factor on the level of pensions becomes clearer if one explains the formula for calculating the replacement rate for lost earnings of an insured person employed in the Russian Federation (Rr): 
$\mathrm{Rr}=\mathrm{Pav} / \mathrm{Sav},(1)$

Pav -average size of old-age pension in the whole country,

Sav -average wage in the country.

The size of the average old-age pension in the whole country (Pav) is calculated using the following formula:

Pav = (Sav $x$ Ir $x$ Ni)/Npen, (2)

Ir - insurance premium rate for statutory pension insurance,

$\mathrm{Ni}$ - number of insured persons in the statutory pension insurance (in fact, it is the entire working population of the country),

Npen - number of old-aged pensioners.

When converting the formula (1) the following is obtained:

$\mathrm{Ni}=(\mathrm{It} \times \mathrm{Ni}) / \mathrm{Npen}(3)$

It can be concluded that the larger is the ratio of the number of employed people who pay insurance premiums, and the number of pension recipients, the greater is the value of the replacement rate for the lost earnings of an insured person.

Currently $3 / 4$ or $71 \%$ of the Russian population are paid below the average in the economy (Table 2). And if one takes the median wage, that is, to exclude from its calculation the highest-paid and lowest-paid categories, the salary in the country would be on average only 17,000 rubles per month instead of 26,000 rubles. The simplest calculation shows that a $40 \%$ replacement rate of such wages will be 6800 rubles, which exceeds the subsistence level established in the Russian Federation in 2013 only by 669 rubles.

Table 2. The structure of paid employment, depending on the amount of earnings in the Russian Federation in 20122013

\begin{tabular}{|l|c|c|c|c|}
\hline \multirow{2}{*}{ Indicator of number } & \multicolumn{2}{|c|}{2012} & \multicolumn{2}{|c|}{2013} \\
\cline { 2 - 5 } & number mln.people. & $\begin{array}{c}\text { ratio } \\
\%\end{array}$ & $\begin{array}{c}\text { number mln.people. } \\
\%\end{array}$ & $\begin{array}{c}\text { ratio, } \\
\%\end{array}$ \\
\hline The number of paid employers - all of them with wages:: & 46,55 & 100 & 46,35 & 100 \\
\hline Below average in the economy & 30,35 & 65,2 & 30,22 & 65,2 \\
\hline Equal to average in the economy & 3,13 & 6,7 & 3,11 & 6,7 \\
\hline Above average in the economy & 13,07 & 28,1 & 13,02 & 28,1 \\
\hline
\end{tabular}

Russia has used the solidarity replacement rate, which is calculated as the ratio of the average pension for all recipients in the current year and the average wage in the economy over the same period, expressed as a percentage. ILO Convention \# 102 "Minimum Standards of Social Security" [2] and the European Code of Social Security [8] provide the calculation of the replacement rate as the ratio of a typical beneficiary pension and his previous income. The replacement rate is set at $40 \%$ only for typical recipients the main requirement to whom is 30 years of insurance employment (for oldage pensions)

The typical pension recipients usually include the majority of people; they can be regarded as the middle class in the general population and retirees. The typical pension recipient according ILO Convention \# 102 is, in particular, a skilled manual male employee whose salary is equal to $125 \%$ of the average wage of all the persons to be provided, who at the same time, has 30 years of insurance contributions or employment. For the rest of pensioners the norms of replacement rate are proportionally reduced. In this case, the pension should not correlate with wages of other people working at the moment, as is the case of Russia in the calculation of the solidarity replacement rate. Instead it should match the past earnings (income) of the individual in the period prior to the pension [2].

If we calculate the individual replacement rate of a typical recipient of old-age pension using the method of calculation of old-age pension in the Law "On labor pensions in the Russian Federation", when the insurance period is 30 years, while monthly wage is 30000 rubles, then we obtain the following results. Estimated pension assets for the year will be 4800 rubles (16\% of earnings), and for 30 years - 48 monthly salaries. Their sum (144 000) should be divided by 228 months (the expected period for receiving the pension). The typical pension will be $21 \%$ of monthly earnings. Given a fixed base size (and it is about one third of the pension) pension will be about $30 \%$ of the salary, which is $10 \%$ less than the international standard [9]. For high-income segment of the population the individual replacement rate will be even less [10]. 


\section{Conclusion}

Currently it is very difficult to give a reliable estimation to the level of pensions in Russia by international standards. Firstly, it is impossible to calculate the replacement rate for current recipients of pensions using international methodology, since during the Soviet period payroll accounting was not organized for the entire length of service, and only the best 2 or 5 years were taken for calculating the pension. This indicator can be applied to insured persons who started to form their pension rights after 2002 not until 2032.

Secondly, it is not right to assess the level of pensions on the basis of the average wage in the country and the average pension of all recipients, as it is done in Russia, because currently more than $70 \%$ of the population receive a salary lower than its average size in the country. Besides, the size of different pension types vary significantly (for example, in 2013 the average social pension was 6,446.4 rubles and pension to test-pilots was 67,704.0 rubles).

Of course, in order to ensure the comparability of the calculation of the pension replacement rate for lost earnings with international standards it is necessary to reconsider the existing Russian methodology for calculating this coefficient [11]. In addition, we believe that under current conditions it would be more correct to assess the level of pension income of retirees by the ratio of pension to the subsistence level, which is calculated on the basis of the consumer goods value. According to the experts of the Pension Fund of the Russian Federation, today the ratio of average pension to the subsistence level is about 180\%. By 2018 this figure is expected to exceed $200 \%$, and in $2030-250 \%$.

But this raises the question of comparing the calculation methods for subsistence minimum in Russia and in other countries, as there are differences in the methods of evaluation. Thus, upon ratification of the ILO Convention \# 102 by the Russian Federation the method of calculating the replacement rate for lost earnings of the insured person will be reviewed and, respectively, comparison of the Russian Federation with other countries will be more correct.

\section{References}

Shevchuk, N. Ways of pension system improving as a factor of state's social security// Economic Annals-XXI, 2014, 1-2 (2), pp. 36-39; ILO Convention No. 102. Social Security (Minimum Standards) Convention, 1952

Staubli, S., Zweimüller, J. Does raising the early retirement age increase employment of older workers?// Journal of Public Economics, 2013, 108, pp. 17-32;

Broeders, D., Chen, A. Pension Benefit Security: A Comparison of Solvency Requirements, a Pension Guarantee Fund, and Sponsor Support // Journal of Risk and Insurance, 2013, 80 (2), pp. 239-272;

Phan, H.V., Hegde, S.P. Corporate governance and risk taking in pension plans: Evidence from defined benefit asset allocations // Journal of Financial and Quantitative Analysis, 2013, 48 (3), pp. 919-946;

Jung, J., Tran, C. The extension of social security coverage in developing countries // Journal of Development Economics, 2012, 99 (2), pp. 439-458;

Olov'ev, A.K. Long-term forecasting of the development of Russia's pension system: Factors and conditions // Russian Economic Development, 2012, 23 (3), pp. 271-281.

European Code of Social Security: Strasbourg, 16 April 1964

Goecke, O. Pension saving schemes with return smoothing mechanism// Insurance: Mathematics and Economics, 2013, 53 (3), pp. 678689;

Guillén, M., Perch Nielsen, J., Pérez-Marín, A.M., Petersen, K.S. Performance measurement of pension strategies: A case study of Danish life cycle products // Scandinavian Actuarial Journal, 2012, (4), pp. 258-277;

Bikker, J.A., Broeders, D.W.G.A., Hollanders, D.A., Ponds, E.H.M Pension Funds' Asset Allocation and Participant Age: A Test of the Life-Cycle Model // Journal of Risk and Insurance, 2012, 79 (3), pp. 595-618;

Špirková, J., Spišiaková, M. The impact of some risk factors on the amount of pension from the third pillar pension// Ekonomicky casopis, Volume 62, Issue 1, 2014, Pages 71-82

Ptashchenko, L.O., Topol, V.V. Document Formation of a balanced model of ukrainian nongovernment pension insurance system// Problems of Economics 2014, 155 (5), pp. 528-537

Guiso, L., Jappelli, T., Padula, M. Pension wealth uncertainty/l Journal of Risk and Insurance, 2013, 80 (4), pp. 1057-1085;

Crossley, T., Jametti, M. Pension benefit insurance and pension plan portfolio choice// Review of Economics and Statistics, 2013, 95 (1), pp. 337-341;

Fehr, H., Kallweit, M., Kindermann, F. Should pensions be progressive?// European Economic Review, 2013, 63, pp. 94-116;

Cox, S.H., Lin, Y., Tian, R., Yu, J. Managing capital market and longevity risks in a defined benefit pension plan// Journal of Risk and Insurance, 2013, 80 (3), pp. 585-619; 